\title{
Analisis Senyawa Bioaktif Ekstrak Metabolit Sekunder Serratia marcescens strain MBC1
}

\author{
Yusifa Arsy Variani ${ }^{\mathrm{a},}$, Endah Setyaningrum ${ }^{\mathrm{a}}$, Kusuma Handayani ${ }^{\mathrm{a}}$, Nismah Nukmal ${ }^{\mathrm{a}}$, Achmad \\ Arifiyanto $^{\mathrm{a}}$ \\ ${ }^{a}$ Jurusan Biologi, Universitas Lampung \\ * corresponding author : yusifarsyy@gmail.com \\ DOI: $10.20885 / \mathrm{ijca} . v 014$.iss 2 .art3
}

\section{ARTIKEL INFO}

Diterima : 17 Juli 2021

Direvisi. : 25 Agustus 2021

Diterbitkan: 18 September 2021

Kata kunci : Serratia marcescens

MBC1, Metaboli sekunder,

Antibakteri

\begin{abstract}
ABSTRAK
Serratia marcescens strain MBC1 merupakan bakteri gram negatif yang dapat menghasilkan beberapa senyawa bioaktif. Berdasarkan penelitian sebelumnya, diketahui bahwa bakteri ini mampu mendegradasi berbagai macam enzim dan memiliki berbagai macam aktivitas biologis seperti antibakteri, antikanker, biosurfaktan dan sebagai bahan obat-obatan. Tujuan penelitian ini adalah untuk mengetahui kandungan senyawa bioaktif yang terdapat pada ekstrak metabolit sekunder Serratia marcescens strain MBC1. Pada penelitian ini dilakukan beberapa uji yaitu, uji fitokomia dan uji FT-IR. Hasil uji fitokimia menunjukkan bahwa ekstrak Serratia marcescens strain MBC1 mengandung senyawa golongan alkaloid dan saponin. Hasil uji FT-IR menunjukkan adanya kemiripan gugus fungsi yang dimiliki oleh ekstrak S.marcescens strain MBC1 dengan senyawa golongan alkaloid. Namun, perlu adanya penelitian lebih lanjut mengenai kandungan senyawa metabolit yang terkandung dalam ekstrak $S$. marcescens dan aktivitas biologisnya sebagai antimalaria, antibakteri, antifungi dan sebagai bahan obat-obatan.
\end{abstract}

\begin{tabular}{l} 
ARTICLE INFO \\
\hline Received : 17 July 2021 \\
Revised : 25 August 2021 \\
Published: 18 September 2021 \\
Keywords: Serratia marcescens, \\
Secondary metabolite, antibacterial
\end{tabular}

\section{ARTICLE INFO}

Published: 18 September 202

Secondary metabolite, antibacterial

\begin{abstract}
Serratia marcescens strain MBC1 is a gram-negative bacterium that can produce several bioactive compounds. Based on previous studies, it is known that these bacteria are able to degrade various enzymes and have various biological activities such as antibacterial, anticancer, biosurfactant and as an ingredient in medicines. The purpose of this study was to determine the content of bioactive compounds contained in the extract of secondary metabolite Serratia marcescens strain MBC1. In this study, several tests were performed, namely phytochemical test and FT-IR test. Phytochemical test results showed that Serratia marcescens extract of MBCl strain contained alkaloids and saponins. The results of FTIR test showed that there were similarities between the functional group of MBCl strain of $S$. marcescens extract and alkaloid compounds. However, further research is needed on the content of metabolites found in S. marcescens extract and its biological activity
\end{abstract}


as an antimalarial, antibacterial, antifungal and medicinal substance

\section{PENDAHULUAN}

Metabolit sekunder merupakan senyawa yang tidak digunakan sebagai proses pertumbuhan, tetapi sebagai bentuk pertahanan diri dari lingkungannya. Metabolit sekunder terdiri dari molekulmolekul kecil yang mengandung senyawa spesifik dengan fungsi dan peranan yang berbeda [1]. Alkaloid, flavonoid, saponin terpenoid termasuk ke dalam golongan metabolit sekunder yang sering dijumpai pada ekstrak tanaman dan ditemukan dalam ekstrak bakteri [2].

Serratia marcescens merupakan bakteri gram negatif dari family enterobacteriaceae yang termasuk ke dalam bakteri patogen oportunistik. Bakteri ini bersifat motil karena memiliki flagella peritrik. S. marcescens sering ditemukan di air, tanah, permukaan daun serta di dalam tubuh serangga maupun tubuh manusia. Karena mampu hidup dalam tempat yang ekstrim dengan kisaran suhu 5.C $-40 \cdot \mathrm{C}$ dalam kisaran $\mathrm{pH}$ antara 5-9 maka, bakteri ini bersifat fakultatif anaerob [3].

Uji kualitatif $S$. marcecens strain MBC1 diketahui bahwa bakteri tersebut memiliki karakteristik yaitu, sel nya berbentuk batang, motil, dan termasuk ke dalam bakteri gram-negatif. S. marcescens strain MBC1 mengandung pigmen berwarna merah yang disebabkan oleh aktivitas amilolitik dan lipolitik yang dapat dimanfaatkan dalam bidang pertanian maupun sebagai biosurfaktan. Selain itu, bakteri ini juga memiliki kemampuan sebagai antioksidan[4]. Hasil penelitian lain melaporkan bahwa bakteri ini memiliki kemampuan dalam mendegradasi enzim lipase, mannanase, selulase, amilase, dan protease [5]. Uji aktivitas biologis $S$. marcescens melaporkan bahwa bakteri ini memiliki aktivitas sebagai antifungi pada pertumbuhan jamur Alternaria porri [6]. Penelitian mengenai kandungan senyawa metabolit sekunder $S$. marcescens telah banyak dilakukan. Prodigiosin merupakan metabolit sekunder yang biasa ditemukan dalam S. marcescens. Prodigiosin memiliki mekanisme yang sama dengan alkaloid quinine dan quinidine. Prodigiosin yang berasal dari S. marcescens Subsp. lawsoniana diketahui memiliki aktivitas antikanker dan antitumor [7]. Penelitian S. marcescens strain Db10 menemukan adanya kandungan metabolit sekunder althiomycin yang dapat menghambat pertumbuhan bakteri Bacillus subtilis [8]. Serrawatin merupakan salah satu senyawa yang juga ditemukan dalam Serratia yang memiliki aktvitas sebagai biosurfaktan [9].

Penelitian ini menggunakan isolat bakteri Serratia marcescens strain MBC1 yang merupakan koleksi dari Laboratorium Mikrobiologi FMIPA, Universitas Lampung, yang belum diketahui kandungan senyawa bioaktifnya. Penelitian ini terdiri dari uji fitokimia dan uji Fourier Transform Infrared (FT-IR). Uji fitokimia merupakan uji pendahuluan dalam mengidentifikasi ada atau tidaknya senyawa bioaktif yang terkandung dalam suatu ekstrak. Prinsip uji ini yaitu melihat perubahan warna sesuai dengan pereaksi yang digunakan [10]. Uji fitokimia dilakukan untuk mengetahui jenis golongan metabolit sekunder seperti, alkaloid, flavonoid, steroid, fenolik, dan triterpenoid. Uji Fourier Transform Infrared (FT-IR) merupakan suatu metode uji digunakan untuk mengetahui bilangan gelombang yang dapat menunjukkan gugus fungsi senyawa metabolit sekunder seperti golongan alkaloid, flavonoid, tanin, saponin terpenoid. Kelebihan dari uji FT-IR diantaranya, waktu analisis singkat, biaya terjangkau, dapat digunakan secara simultan pada bermacam-macam frekuensi sumber cahaya. Berdasarkan uraian di atas, maka tujuan penelitian ini adalah untuk mengetahui kandungan senyawa bioaktif yang terdapat pada ekstrak metabolit sekunder Serratia marcescens strain MBC1 dengan melakukan uji fitokomia dan uji FT-IR.

\section{METODE}

\subsection{Bahan Penelitian}

Isolat Serratia marcescens strain MBC1, media Triptone water, media TSA (Tryptic Soy Agar), aquades, alkohol 70\%, pelarut etil asetat, methanol, kertas saring whatman nomor 40, pereaksi Dragendroff, pereaksi Mayer, $\mathrm{Pb}$ Asetat $10 \%, \mathrm{NaOH}, \mathrm{FeCl}_{3} 5 \%$ dan 10\%, kloroform, Asam asetat glasial, $\mathrm{H}_{2} \mathrm{SO}_{4}$ pekat, $\mathrm{HCl}$. 


\subsection{Prosedur Kerja}

\subsubsection{Sub-kultur Serratia marcescens strain MBC1}

Isolat S. marcescens strain MBC1 di sub-kultur pada media TSA (Tryptic Soy Agar) kemudian diinkubasi di inkubator pada suhu $37^{\circ} \mathrm{C}$ selama 7 hari [4].

\subsubsection{Fermentasi Serratia marcescens strain MBC1}

Isolat Serratia marcescens strain MBC1 sebanyak 1 ose diinokulasi ke dalam $100 \mathrm{~mL}$ media Triptone Water, diinkubasi pada shaker inkubator pada suhu $32^{\circ} \mathrm{C}$ selama 7 hari.

\subsubsection{Produksi Metabolit Sekunder}

Hasil Fermentasi isolat Serratia marcescens strain MBC1 dipindahkan ke dalam 1 L media Triptone water, lalu diinkubasi pada inkubator shaker dengan suhu $32^{\circ} \mathrm{C}$ selama 7 hari. Hasil fermentasi disaring untuk memisahkan natan dan supernatan dengan menggunakan kertas saring Whatman no.40. Hasil saringan ditambahkan dengan $500 \mathrm{~mL}$ etil asetat dan $500 \mathrm{~mL}$ metanol. Pelarut etil asetat dan metanol dipisahkan dengan menggunakan rotary evaporator. Hasil ekstrak metabolit sekunder disimpan di lemari pendingin.

\subsubsection{Uji Fitokimia}

Uji alkaloid dilakukan dengan menguapkan $2 \mathrm{~mL}$ ekstrak pada cawan porselen hingga diperoleh residu. Kemudian, residu dilarutkan dengan $5 \mathrm{~mL} \mathrm{HCl} 2 \mathrm{~N}$. Lalu, dibagi ke dalam 2 tabung dan ditambahkan dengan pereaksi Mayer dan pereaksi Dragendorff pada masing-masing tabung. Uji positif ditandai dengan adanya endapan jingga pada pereaksi Mayer dan endapan berwarna kuning pada pereaksi Dragendorff [11].

Identifikasi flavonoid dilakukan dengan sebanyak $1 \mathrm{~mL}$ ekstrak dimasukkan ke dalam 3 tabung reaksi. Tabung 1 ditambahkan $1 \mathrm{~mL}$ pereaksi $\mathrm{Pb}$ asetat $10 \%$, Tabung 2 ditambahkan beberapa tetes pereaksi $\mathrm{NaOH} 20 \%$, dan tabung 3 sebagai kontrol. Adanya senyawa flavonoid ditandai dengan terbentuknya endapan berwarna kuning pada ekstrak yang ditambahkan $\mathrm{Pb}$ asetat $10 \%$ dan adanya perubahan warna kuning pada ekstrak yang ditambah pereaksi $\mathrm{NaOH} \mathrm{20 \%} \mathrm{[12].}$ Saponin diuji keberadaannya dengan cara $4 \mathrm{~mL}$ ekstrak dicampur dengan $5 \mathrm{~mL}$ aquades, kemudian dikocok. Uji positif ditandai dengan adanya busa stabil setinggi $1 \mathrm{~cm}$ selama 10 menit [12]. Identifikasi triterpenoid atau steroid dilakukan dengan menguapkan ekstrak sebanyak $2 \mathrm{~mL}$ hingga terbentuk residu, lalu dimasukkan ke dalam tabung reaksi. Hasil residu ditambahkan $0.5 \mathrm{~mL}$ kloroform. Setelah itu, ditambahkan dengan $0.5 \mathrm{~mL}$ asam asetat glasial dan $2 \mathrm{~mL}$ asam sulfat pekat. Pembentukan cincin kecoklatan atau violet pada perbatasan larutan menunjukkan adanya senyawa triterpenoid, sedangkan munculnya cincin biru kehijauan menunjukkan adanya senyawa steroid [12]. Identifikasi tanin dilakukan dengan cara sebanyak $2 \mathrm{~mL}$ ekstrak ditambah pereaksi $\mathrm{FeCl}_{3} 5 \%$ atau $\mathrm{FeCl}_{3} 10 \%$. Hasil positif ditunjukkan dengan adanya perubahan warna biru atau hijau gelap [13]. Antraquinon glikosida diidentifikasi dengan cara sebanyak $50 \mathrm{mg}$ sampel ditambah $10 \mathrm{~mL}$ aquades. Lalu, dipanaskan dan disaring. Setelah disaring ditambahkan dengan pereaksi $\mathrm{NaOH} 1 \mathrm{~N}$. Hasil positif apabila terbentuk larutan berwarna merah [12].

\subsubsection{Uji FT-IR}

Uji FT-IR dilakukan menggunakan alat FT-IR merk dagang Nicolet iS 10, pada panjang gelombang 400-4000 $\mathrm{cm}^{-1}$. Uji FT-IR dilaksanakan di Laboratorium Pengolahan Material dan Mineral ITS Surabaya

\section{HASIL PENELITIAN}

\subsection{Uji Fitokimia}

Uji fitokimia merupakan uji pendahuluan yang digunakan untuk mengetahui ada atau tidaknya kandungan senyawa metabolit sekunder yang terdapat dalam suatu ekstrak. Senyawa metabolit digolongkan menjadi beberapa jenis berdasarkan struktur kimianya diantarnya golongan alkaloid, flavonoid, saponin, triterpenoid, steroid, tanin, dan antraquinon glikosida. Hasil uji fitokimia 
ekstrak metabolit sekunder $S$. marcescens strain MBC1 disajikkan pada Tabel 1

TABEL I Hasil Uji Fitokimia Ekstrak Metabolit Sekunder S. marcescens strain MBC1

\begin{tabular}{|c|c|c|}
\hline \multirow{2}{*}{ Uji Fitokimia } & \multirow{2}{*}{ Pereaksi } & Hasil \\
\hline & & S. marcescens \\
\hline \multirow[t]{2}{*}{ Alkaloid } & Dragendroff & + \\
\hline & Mayer & - \\
\hline \multirow[t]{2}{*}{ Flavonoid } & $\mathrm{Pb}$ Asetat $10 \%$ & - \\
\hline & $\mathrm{NaOH} 20 \%$ & - \\
\hline Saponin & Aquades & + \\
\hline Tanin & $\mathrm{FeCl} 35 \%$ atau $\mathrm{FeCl} 310 \%$ & - \\
\hline Triterpenoid & $\begin{array}{l}\text { Asam Asetat Anhidrat }+\mathrm{H}_{2} \mathrm{SO} 4 \\
\text { pekat }\end{array}$ & - \\
\hline Antraquinon Glikosida & $\mathrm{NaOH} 1 \mathrm{~N}$ & - \\
\hline
\end{tabular}

Keterangan :

$(+)=$ teridentifikasi

$(-)=$ tidak teridentifikasi

Hasil uji fitokimia ekstrak metabolit sekunder $S$. marcescens strain $\mathrm{MBC} 1$ menunjukkan bahwa ekstrak $S$. marcescens strain MBC1 positif mengandung senyawa alkaloid dan dan saponin. Hal ini didukung oleh adanya perubahan warna yang terjadi pada uji alkaloid yang ditambahkan dengan pereaksi Dragendorff, sedangkan hasil uji positif mengandung saponin karena terbentuknya busa stabil. Metabolit sekunder yang terkandung dalam ekstrak $S$. marcescens diketahui memiliki berbagai aktivitas biologis yang berperan penting di dalam kehidupan.
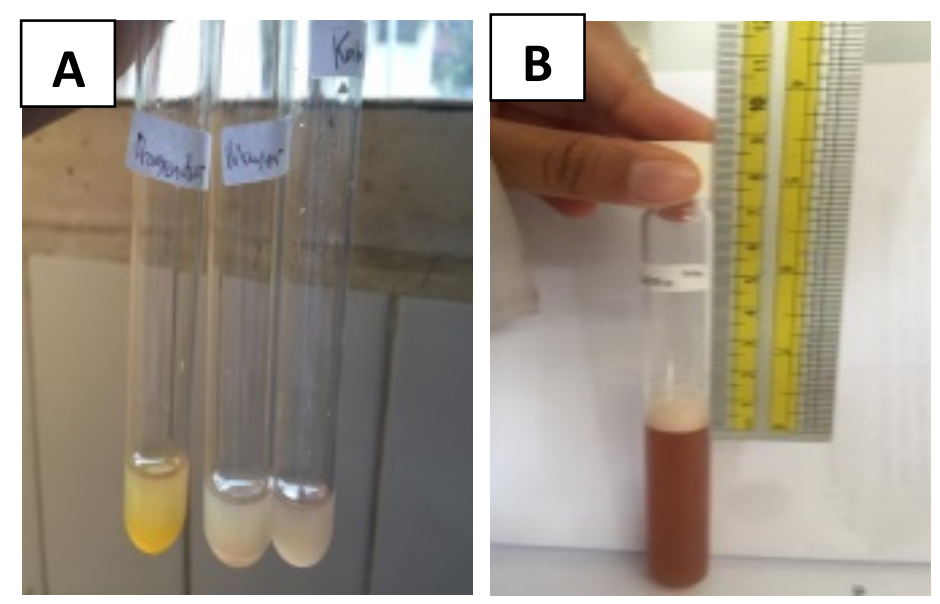

Gambar 1. Hasil Uji Fitokimia bakteri S. marcescens strain MBC1, (A) Uji Positif Alkaloid, (B) Uji Positif Saponin

Ekstrak S. marcescens teridentifikasi memiliki kandungan senyawa alkaloid. Hasil uji positif alkaloid sejalan dengan penelitian Renta (2015) yang menyatakan bahwa bakteri Serratia marcescens dapat memproduksi alkaloid jenis prodiginin, yaitu senyawa prodigiosin. Prodigiosin merupakan metabolit sekunder yang termasuk ke dalam golongan alkaloid dengan struktur kimia tripyrrole yang unik. Biasanya prodigiosin berbentuk pigmen merah yang diisolasi dari Serratia, Pseudomonas dan Streptomyces [15]. Alkaloid memiliki bioaktivitas sebagai antibakteri. Alkaloid 
bekerja sebagai antibakteri dengan merusak enzim DNA dan RNA polimerase, sehingga menghambat sintesis DNA dan RNA. Alkaloid juga menghambat pembentukan dinding sel dengan mengganggu pembentukan peptidoglikan yang menyebabkan sel menjadi lisis [16].

Ernawati (2018) mengungkapkan bahwa senyawa golongan alkaloid memiliki aktivitas biologis yang cukup berpotensi dalam berbagai aspek. Hasil penelitiannya melaporkan bahwa alkaloid memiliki potensi sebagai antimalaria, juga memiliki aktivitas sebagai antikanker, antimalaria, antioksidan, antiinflamasi. Golongan alkaloid diantaranya morfin, kafein, kikine, kokain, dan atropine berperan sebagai pereda nyeri dan penghilang rasa sakit dalam bidang farmasi [17]. Hasil uji positif mengandung senyawa alkaloid disajikkan pada Gambar 1.

Berdasarkan Gambar 1, ekstrak $S$. marcescens strain MBC1 juga mengandung senyawa saponin. Hal ini terbukti dengan adanya busa stabil setinggi $1 \mathrm{~cm}$. Saponin berasal dari kata 'Sapo' yang artinya sabun. Penelitian yang dilakukan oleh Matthew et al. (2018) melaporkan bahwa senyawa saponin memiliki aktivitas antimalaria karena dapat menghambat polimerisasi heme. Hal ini sesuai dengan penelitian Streptomyces hygroscopicus subsp hygroscopicys strain I18 mengandung senyawa saponin yang berpotensi sebagai antimalaria karena dapat menghambat pertumbuhan plasmodium [19]. Penelitian Rijayanti (2014) melaporkan bahwa kandungan saponin pada daun mangga bacang berpotensi menjadi antibakteri karena dapat menghambat pertumbuhan bakteri Staphylococcus aereus. Hal ini sejalan dengan penelitian ekstrak teripang pasir (Holothuria scabra) yang dapat menghambat pertumbuhan bakteri Pseudomonas aeruginosa dan Bacillus cereus. Senyawa ini berperan sebagai antibakteri karena dapat membuat sel rusak dengan cara menembus membran sel bakteri [21]. Pada usus manusia diketahui bahwa saponin dapat mengurangi risiko kanker usus besar dengan mengikat asam empedu primer sehingga dapat menekan produksi asam empedu sekunder [10]. Penelitian lain mengungkapkan bahwa saponin memiliki potensi sebagai antivibrosis [22].

\subsection{Uji Fourier Transform Infrared (FT-IR)}

Uji FT-IR dilakukan dengan menggunakan alat FT-IR merk dagang Nicolet iS 10. Alat ini terdiri dari komponen mid-infrared Ever-Glo dan Tungsten atau Halogen yang dapat disesuaikan dengan kebutuhan sampel uji. Spektrometer merk dagang Nicolet iS 10 memiliki kemampuan yang akurat dalam melakukan olah data yang digunakan untuk menganalisis material. Hal ini karena alat terebut mempunyai spesifikasi ASTM E1421 dengan standar ISO/GLP [23]. Serapan standar biasa muncul pada bilangan gelombang $4000-400 \mathrm{~cm}^{-1}$. Uji FT-IR digunakan untuk mengetahui bilangan gelombang dari senyawa murni yang dapat menunjukkan gugus fungsi yang dimiliki senyawa tersebut Kelebihan dari uji FT-IR diantaranya, waktu analisis singkat, biaya terjangkau, dapat digunakan secara simultan pada bermacam-macam frekuensi sumber cahaya Hasil spektrum IR ekstrak metabolit sekunder S. marcescens strain MBC1 disajikkan pada Gambar 2.

Hasil analisis FT-IR menunjukkan bahwa adanya pita melebar pada daerah bilangan gelombang $3373 \mathrm{~cm}^{-1}$ yang merupakan vibrasi ulur dari gugus hidroksil yang dapat membentuk ikatan hidrogen. Munculnya serapan pada bilangan gelombang $1579 \mathrm{~cm}^{-1}$ dan $1406 \mathrm{~cm}^{-1}$ mengindikasi adanya gugus $\mathrm{C}=\mathrm{C}$ aromatik. Bilangan gelombang $1516 \mathrm{~cm}^{-1}$ mengindikasi adanya gugus $\mathrm{N}-\mathrm{H}$. Sedangkan serapan pada bilangan gelombang $1245 \mathrm{~cm}^{-1}$ mengindikasi adanya gugus $\mathrm{C}-\mathrm{OH}$. Berdasarkan hasil interpretasi tersebut diduga gugus fungsi $S$. marcescens memiliki kemiripan dengan senyawa alkaloid [24]. Menurut Irindah (2010), pada bilangan gelombang 3373 $\mathrm{cm}^{-1}$ spektra terlihat lebih lebar karena adanya tumpang tindih (overlapping) yang terjadi pada beberapa bilangan gelombang spektra FT-IR. Berdasarkan hasil uji fitokimia dan uji FT-IR senyawa yang terkandung dalam ekstrak $S$. marcescens strain $\mathrm{MBC} 1$ termasuk ke dalam golongan senyawa alkaloid. 


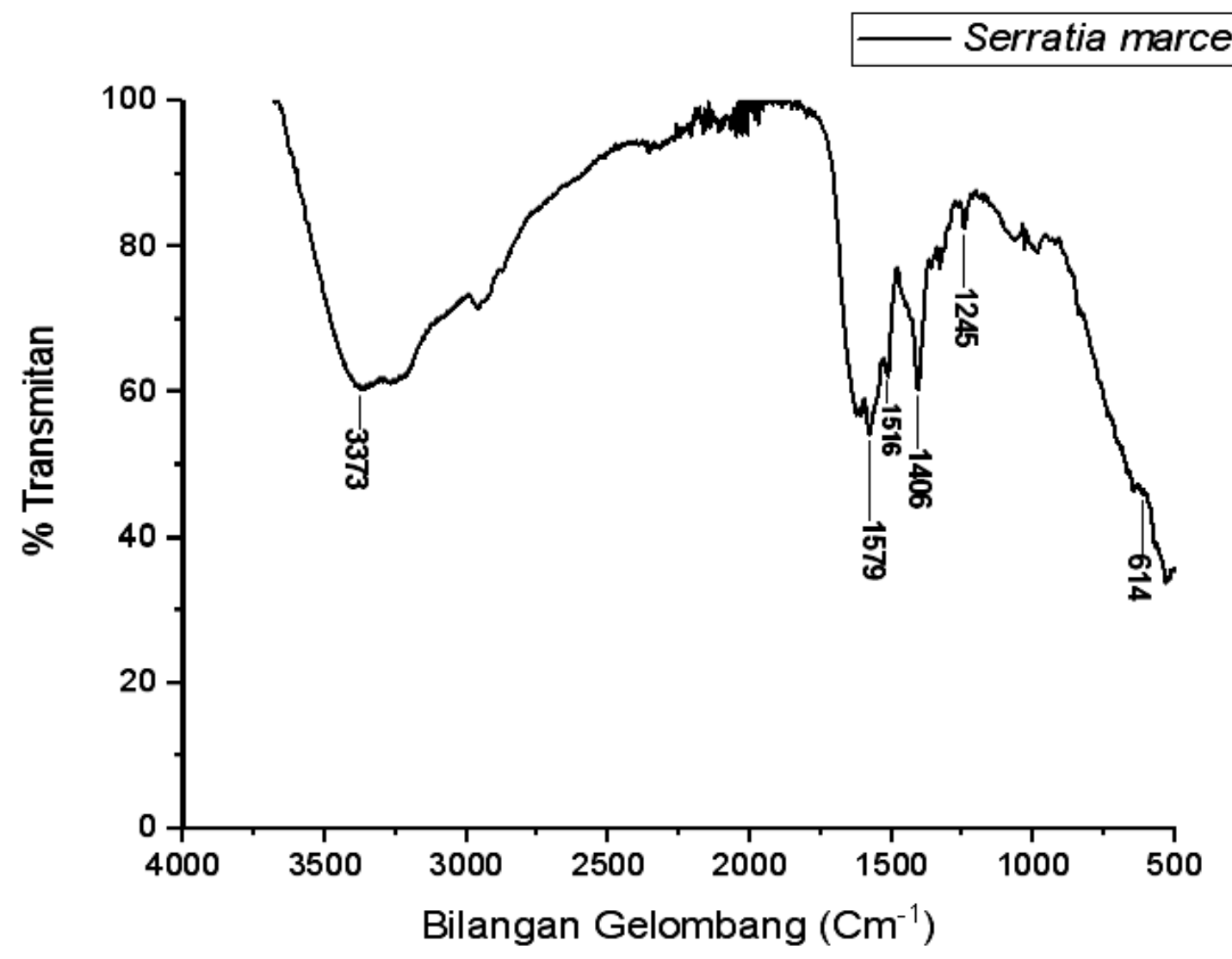

Gambar 2. Hasil Spektrum FT-IR Ekstrak S. marcescens strain MBC1

\section{KESIMPULAN}

Senyawa metabolit sekunder yang terdapat pada ekstrak $S$. marcescens stain MBC1 yaitu alkaloid dan saponin. Hal ini diperkuat dengan hasil spektrum IR yang menunjukkan adanya kemiripan dengan gugus fungsi alkaloid. Namun, perlu adanya penelitian lebih lanjut mengenai kandungan senyawa metabolit yang terkandung dalam ekstrak $S$. marcescens yang berpotensi sebagai antimalaria, antibakteri, antifungi dan sebagai bahan obat-obatan.

\section{Ucapan Terimakasih}

Ucapan terimakasih penulis sampaikan kepada Universitas Lampung yang telah memberikan dana hibah dalam penelitian ini. Ucapan terimakasih kepada Laboratorium Pengolahan Material dan Mineral ITS Surabaya yang telah membantu dalam penelitian ini.

\section{Daftar Pustaka}

[1] S. Sumarwoto, S. Susilowati, Y. Adhityanti, "Uji Sirih Merah ( Piper crocatum ) Pada Berbagai Intensitas Sinar Matahari dan Media Tanam", J Pertanian Mapeta, vol. 11, pp 1-8, 2008

[2] W. F. Dewatisari, L. Rumiyanti, I. Rakhmawati, "Rendemen dan Skrining Fitokimia pada Ekstrak Daun Sanseviera sp . Rendemen and Phytochemical Screening using Leaf extract of Sansevieria Sp", J Penelit Pertan Terap, vol. 17(3), pp. 197-202, 2018

[3] C, I. Dalimunthe, A. Dahlan, R. Tistama "Potensi Bakteri Serratia sp. Sebagai Agensia Hayati Penyakit Jamur Akar Putih (Rigidoporus microporus)", J Agro Estate

[4] A. Arifiyanto, H. Afriani, M. H. Putri, B. Damayanti, C. L. R. Riyanto, "The biological prospective of red-pigmented bacteria cultured from contaminated agar media", Biodiversitas. vol. 
22(3), pp. 1152-1159, 2021.

[5] M. H. Putri, K. Handayani, W. A. Setiawan, B. Damayanti, C. L. Ratih, A. Arifiyanto, "Screening of Extracellular Enzymes on Serratia marcescens strain MBC1", J Ris Biol dan Apl., vol 1, 23, 2021.

[6] U. Nasiroh, I. Isnawati, G. Trimulyono, "Aktivitas Antifungi Serratia marcescens terhadap Alternaria porri Penyebab Penyakit Bercak Ungu Secara in Vitro", LenteraBio., vol. 4(1), pp. 13$18,2000$.

[7] D. Li, J. Liu, X. Wang, et al., "Biological potential and mechanism of prodigiosin from Serratia marcescens subsp. Lawsoniana in human choriocarcinoma and prostate cancer cell lines", Int $J$ Mol Sci., vol. 19(11), 2018

[8] A. J. Gerc, N. R Stanley-Wall, S. J. Coulthurst, "Role of the phosphopantetheinyltransferase enzyme, PswP, in the biosynthesis of antimicrobial secondary metabolites by Serratia marcescens Db10", Microbiol (United Kingdom), 2014.

[9] G. Soberón-Chávez, R. M. Maier, "Biosurfactants A General Overview", 2011.

[10] D. E. Saragih, E. V. Arsita, "Kandungan fitokimia Zanthoxylum acanthopodium dan potensinya sebagai tanaman obat di wilayah Toba Samosir dan Tapanuli Utara, Sumatera Utara", Pros Semin Nas Masy Biodiversitas Indones., vol. 5(1), pp. 71-76, 2019.

[11] N. R. Farnsworth, "Biological and phytochemical screening of plants", J Pharm Sci., 1966.

[12] P. E. S. K.Yuda, E. Cahyaningsih, N. P. Y. Winariyanthi, "Skrining Fitokimia Dan Analisis Kromatografi Lapis Tipis Ekstrak Tanaman Patikan Kebo (Euphorbia hirta L.)", J Ilm Medicam. vol. 3(2), pp. 61-70, 2017.

[13] W. S. Putri, N. K. Warditiani, L. P. F. Larasanty, "Skrining Fitokimia Ekstrak Etil Asetat Kulit Buah Manggis ( Garcinia Mangostana L .)", J Pharmacon. vol. 9(4), pp. 56-59, 2013.

[14] R. V. Siregar, "Uji Aktivitas Anti Bakteri Isolat Bakteri Endofit Kemenyan (Styrax benzoin) Asal Tapanuli Utara Sumatera Utara", 2015

[15] Y. Zhao, Q. Cheng,, Z. Shen, B. Fan, Y. Xu, Y. Cao, F. Peng, J. Zhao "Structure of Prodigiosin From Serratia marcescens NJZT-1 And Its Cytotoxicity On TSC2-null Cells", Food Sci. Technol, vol. 41(1).

[16] T. Milanda, K. Lestari, N. T. I. Tarina. Soares, "Antibacterial Activity of Parijoto (Medinilla speciosa Blume) Fruit Against Serratia marcescens and Staphylococcus aureus", IJPST. vol. 8(2), pp. 76-85, 2021.

[17] H. Omar, M. Fadaeinasab, H. Taha, A. Widyawaruyanti, M. A. Nafiah, T. Rachmatiah, "Aporphine alkaloids with in vitro antiplasmodial activity from the leaves of Phoebe tavoyana", $J$ Asian Nat Prod Res., vol. 22(1), pp. 52-60, 2020.

[18] A. O. Matthew, E. Olusola, O. Ademola, A. Aderotimi, J. Adebola, "Anti-malarial Activity of Total Saponins from Terminalia avicennioides and Its Effect on Liver and Haematological of Infected Mice", Drug Des. vol. 7(2), pp. 1-6, 2018.

[19] E. Setyaningrum, A. Arifiyanto, N. Nukmal, "In vitro Test for Inhibition of Plasmodium falciparum 3D7 Parasites using Streptomyces hygroscopicus subsp . hygroscopicus Strain i18, Isolated from a Pineapple Farm in Lampung", J Pure Appl Microbiol., 2021.

[20] R. P. Rijayanti, "Uji Aktivitas Antibakteri Ekstrak Etanol Daun Mangga Baacang (Mangifera foetida L.) Terhadap Staphylococcus aureus Secara In Vitro", 2014.

[21] S. Nimah, W. ruf, A. Trianto, "Uji Bioaktivitas Ekstrak Teripang Pasir (Holothuria Scabra) Terhadap Bakteri Pseudomonas aeruginosa Dan Bacillus cereus", J Pengolah dan Bioteknol Has Perikan., vol. 1(1), pp. 9-17, 2021.

[22] S. A. Devi, W. A. Setyati, D. A. Wulandary, S. Ega, S. I. Muchlissin, "Bioaktivitas Antivibrosis Dan Identifikasi Golongan Senyawa Pada Ekstrak Yeast Dari Sedimen Ekosistem Mangrove Karimunjawa", J enggano. vol. 3(2), pp. 156-163, 2018. 
[23] A. Pambudi, M. Farid, H. Nurdiansah, "Analisa Morfologi dan Spektroskopi Infra Merah Serat Bambu Betung (Dendrocalamus Asper) Hasil Proses Alkalisasi Sebagai Penguat Komposit Absorbsi Suara", J Tek ITS. vol. 6(2), pp. 441-444, 2017.

[24] R. Aksara, W. J. A. Musa, L. Alio, "Identifikasi Senyawa Alkaloid Dari Ekstrak Metanol Kulit Batang Mangga ( Mangifera indica L )", J Entropi. vol. 8(1), pp. 514-519, 2013.

\section{(c) (†) (O)}

Jurnal IJCA is licensed under aÂ Creative Commons Attribution ShareAlike 4.0 